\title{
Visualizing Theatrical and Novelistic Discourse with Bakhtin
}

Susan Petrilli, University of Bari “Aldo Moro", Bari, Italy

\begin{abstract}
A constant vision in Mikhail Bakhtin's works: polyphonic dialogue, this above all in the novel, but his love for theatre should not be neglected. Consequently, a central focus in Bakhtin's reflections is the polyphonic novel which he first identifies in Dostoevsky's novels. Bakhtin establishes a close relation between the novel, popular culture and carnival, evidencing the carnival component of novelistic discourse, therefore of life. Moreover, as he recounts in his 1973 conversations with Victor Duvakin, his interest in the novel overlapped with theatre, in particular the Moscow Art Theatre. In Bakhtin and Theatre, Dick McCaw relates Bakhtin's vision of art and life to theatre as visualized by Stanislavksy, Meyerhold and Grotowski, each of whom operated a "revolution" in their own original terms comparable to the so-called "Bakhtinian revolution" in philosophy of language and literary criticism. With the difficult socio-political events of the time on the background, this essay explores important aspects of the real dialogue between these three masters of the theatre and of the ideal dialogue established between the latter and Bakhtin, thereby creating a special perspective on theatre with special reference to the Bakhtinian concepts of "polyphony" and "dramatization". Overall are evidenced, for the quality of life, the importance of such values as dialogism, otherness, participative unindifference, creativity which also emerge as characteristics that specify the artwork, whether novelistic or theatrical, thereby showing how art and life are vitally interrelated and capable of enhancing each other.
\end{abstract}

\section{KEYWORDS}

Carnival Imagery, Dialogic Vision, Otherness, Polyphony, Unfinalizability

\section{SPEAKING OF THEATRE: BAKHTIN IN CONVERSATION WITH DUVAKIN}

That Mikhail M. Bakhtin (1895-1975) dedicated almost all of his works to novelistic discourse is renowned. We also know that he was fascinated by its manifestation in the polyphonic form as conceived by Fyodor Dostoevsky (1821-1881). Thus, organised the novel, that is, the polyphonic novel was Bakhtin's great love.

In the second 1963 edition of his monograph on Dostoevsky, Problemy poetiki Dostoevskogo (Eng. trans. Problems of Dostoevsky's Poetics, 1984) - the first edition was published in 1929 under the title Problemy tvorčestva Dostoevskogo (Russian and Italian translation now available in Bachtin e il suo circolo 2014: 1053-1423) -, Bakhtin introduces a new element: the connection between novel, polyphony and popular culture, the latter being characterised by that orientation and worldview described as "carnivalesque". Dostoevsky's polyphonic novel avails itself of the carnivalesque component in the novelistic genre. Bakhtin pursued his studies on popular culture and the "carnivalesque" with special reference to François Rabelais and his novel Garantua e Pantagruel 
during the time of his exile. In fact, only two years after the appearance of the1963 edition of his Dostoevsky monograph, Bakhin also published his 1965 monograph Tvorčestvo Fransua Rable i narodnaja kul'tura srednevekov'ja i Renessansa (Eng. trans. Rabelais and His World, 1984) (elaborating on what was originally his doctoral dissertation, written during the 1940s, which the commissars judging his work did not appreciate). The second 1963 edition of Bakhtin's Dostoevsky book was inevitably influenced by his readings of Rabelais.

As to theatre, though not a central focus in Bakhtin's work, it seems that so-called "art theatre" too was one of his passions. Was Bakhtin in love with theatre as well, as a spectator at least? This is a question Viktor Duvakin asked Mikhail Bakhtin during their second conversation of six, all of which took place in 1973 (Besedi VD Duvakina s M. M. Bachtinym 1973, first published in 1996). Bakhtin declared that his experience of the Moscow Art Theatre was not related to Moscow (where indeed he visited every now and again), but to Odessa where he took his university courses.

Bakhtin narrates that as a fan of Konstantin S. Stanislavsky (1863-1938), co-founder of the Moscow Art Theatre inaugurated in 1898, he would go to the "London Hotel" and with his friends they would watch this great master of the theatre through the great window on the first floor, overlooking the road, as he sat in the restaurant eating his meals. This narration led to Duvakin's question: "Therefore, you loved theatre as a spectator?" (in Bakhtin, 2002, p. 9); and Bakhtin's answer: "I can't say that I loved it. I liked it, it had an effect on me, I remember seeing ..., Brandt overwhelmed me," as though to imply that his great love continued to be the polyphonic novel.

\section{BAKHTIN AND THEATRE, A BOOK BY DICK MCCAW}

In Bakhtin and Theatre. Dialogues with Stanislavsky, Meyerhold and Grotowski, published in 2016, the author Dick McCaw relates Bakhtin (see Figure 1) to the theatre directors, Konstantin Stanislavsky (see Figure 2), Vsevolod E. Meyerhold (1874-1940) (see Figure 3) and Jerzy Marian Grotowski (1933-1999) (see Figure 4), creating a special perspective on theatre which we will now explore.

The word "dialogues" in the subtitle of this book alludes to the dialogue that effectively took place in real life between the three masters of the theatre, Stanislavsky, Meyerhold and Grotowski. But "dialogue" can also be interpreted as alluding to the imaginary dialogue and ideal relation established between the latter and Bakhtin. McCaw relates the architectonics of Bakhtin's thought system to theatre as visualized by these masters, with insights that are noteworthy. Stanislavsky, Meyerhold and Grotowski each operate a sort of "revolution" in their own original terms, comparable to Bakhtin's revolution in philosophy of language and literary criticism, the "Bakhtinian revolution" (see Ponzio, 1997, 2015; Petrilli, 1996, 2012a; Petrilli \& Ponzio, 2005).

Stanislavsky founded the Moscow Art Theatre in 1898, giving rise to an intense and complex dialogue with Meyerhold and eventually with the young Polish student Grotowski, who in a sense challenging his predecessors invented the "Poor Theatre" less than twenty years after Stanislavsky's death and Meyerhold's assassination. Bakhtin had similar relations to members of the so-called "Bakhtin Circle", all being connected with him and each other by research itineraries and open dialogue, ever more topical in the present day and age (Petrilli 2016b, 2016c, 2017).

McCaw develops the implications of Bakhtin's reflections on the differences between novel and theatre, referring to a series of central notions in his discourse, including the "chronotope" (see in particular the following publications by Bakhtin: Toward a Philosophy of the Act [1920-1924], 1993; "Forms of Time and of the Chronotope in the Novel" [1937-1938], in Bakhtin, 1981, pp. 84-258; "Author and Hero in Aesthetic Activity" [1920-1924], in Bakhtin, 1990, pp. 4-256; Russian original in Bakhtin, 1979). Our own focus in this essay is on the difference between novel and theatre with reference to the concept of "polyphony," it too pivotal in Bakhtin's writings. The question of polyphony absorbed Bakhtin's attention during the 1920s, ensuing in the first 1929 edition of his monograph on Dostoevsky, published the same year as his arrest and exile to Kustanaj in Kazachstan; and the question of polyphony continued claiming his attention from the 1930s onwards, for the whole time 
of his exile, leading into the enlarged 1963 edition of his Dostoevsky monograph, which marked his first important return to the intellectual scene.

Though Bakhtin was mostly concerned with the novel rather than with dramatic genres, he devoted a great part of his attention to the relation between author and hero. The hero can be a character of the novel as much as a character on stage. Moreover, à propos Dostoevsky (as anticipated, inventor of the new novelistic form denominated by Bakhtin as the "polyphonic novel") and his use of "dialogue," Bakhtin evidenced the concept of "dramatization" (see Ponzio, 2016, 2018; Ponzio, Petrilli \& Ponzio, 2012).

"The important thing in Dostoevsky's polyphony is precisely what happens between various consciousnesses, that is, their interaction and interdependence" (Bakhtin, 1963, p. 36). According to Bakhtin, the profound originality of the creative process as actualized by Dostoevsky lies in the latter's search for words and plots that provoke, tease, extort and ultimately dialogize (p. 39). Dostoevsky's essential dialogism is not exhausted in external dialogue, in other words it is not limited to formal dialogue, to the exchange of rejoinders among characters: "The polyphonic novel is dialogic through and through. Dialogic relationships exist among all elements of novelistic structure; that is, they are juxtaposed contrapuntally," as Bakhtin says (p. 40). Dialogism permeates human speech generally, all relationships and all manifestations of human life, all that has meaning and significance. This is what Bakhtin denominates "substantial dialogue" by contrast to "formal dialogue" (see also Petrilli, 2010, 2012a, 2014a, 2014b, 2014c):

Dostoevsky could hear dialogic relationships everywhere, in all manifestations of conscious and intelligent human life; where consciousness began, there dialogue began for him as well. [...] Thus all relationships among external and internal parts and elements of his novel are dialogic in character, and he structured the novel as a whole as a "great dialogue". Within this "great dialogue" could

Figure 1. Bakhtin and Freud. Painting by Luciano Ponzio for the cover of V. N. Vološinov, Freud e il Freudismo (It. trans. by L. Ponzio, Milan, Mimesis, 2012)

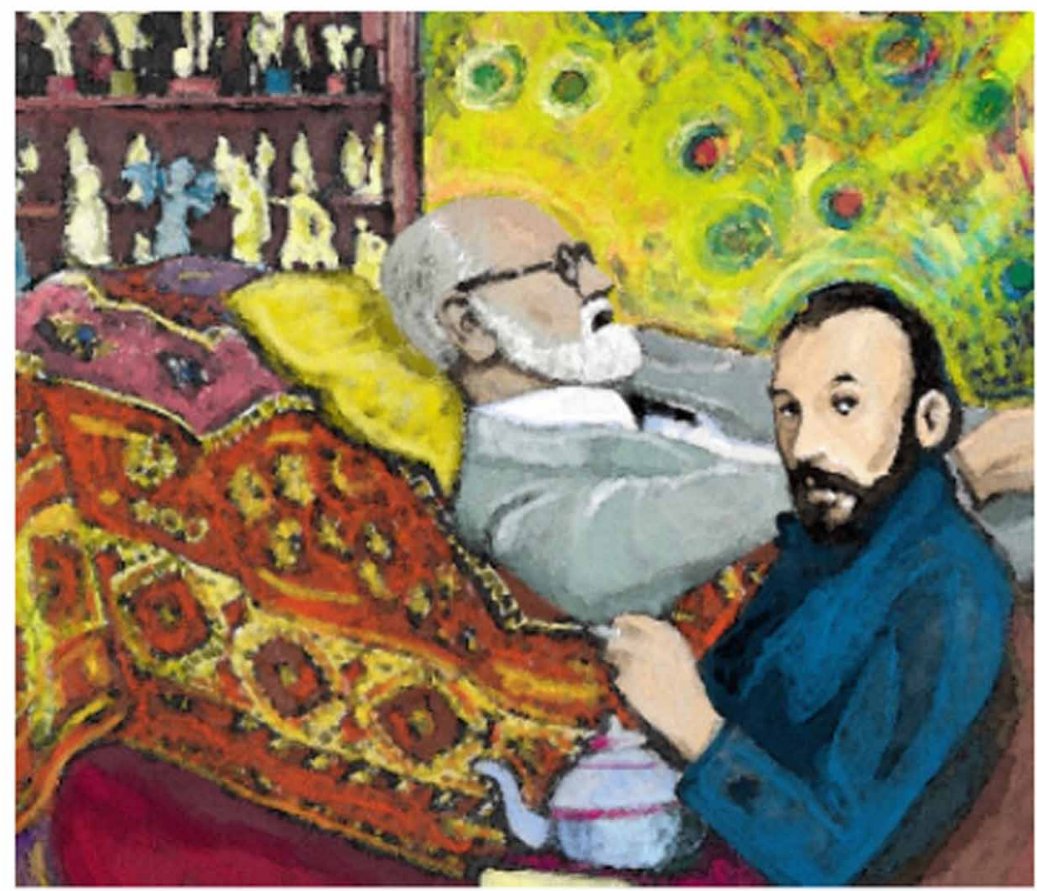


be heard, illuminating it and thickening its texture, the compositionally expressed dialogues of the heroes; ultimately, dialogue penetrates within, into every word of the novel, making it double-voiced, into every gesture, every mimic movement on the hero's face, making it convulsive and anguished; this is already the "microdialogue" that determines the peculiar character of Dostoevsky's verbal style.

As much as the author's voice, the narrating voice, can be heard in the polyphonic novel, the character enjoys high levels of autonomy from the author as in the theatrical artwork. With respect to dramatic genres the difference is that in Dostoevsky's polyphonic novel a relation of mutual interference is established between author and hero, whereas in the traditional novel - to exemplify Bakhtin indicates Balzac - the character becomes the "object" of authorial discourse. In the polyphonic novel (not only Dostoevsky's but in works resulting from his influence) in its different forms through to the present day and age, the character is autonomous, has a word of his / her own, remains in the role of subject with respect to the hero in a relation of difference and at once of interference: "dialogical interference," "substantial dialogue," precisely. The character speaks and acts autonomously and somehow responds to the author - without being conditioned by the author - and is often "unpredictable". Bakhtin uses the adjective "unfinalizable" to indicate that in the polyphonic novel the character is not defined once and for all, is not presented in all its aspects, is not described exhaustively by the author as occurs, instead, in the traditional novel.

On this account, in the epistolary novel Poor Folk (Dostoevsky's first), the protagonist, Makar Devushkin, criticizes Nikolaj V. Gogol' (1809-1852), author of The Overcoat, for reducing his personage Akaky Akakievich Bashmachkin to the status of an object. Gogol' author describes this character meticulously as though he knew him perfectly, to the point that Devushkin in Poor Folk complains about the way his colleague, a white-collar worker like himself, is presented: "it's as though he were already dead before dying". Instead, in Dostoesvsky's polyphonic novel, the voice of the author, no longer an omniscient author, seems itself to be the voice of a character, as though the author too were on stage in an open dialogue with his characters. Of Dostoevsky's works, McCaw pays special attention to The Double (Двойник, Dvojnik) which presents the literary topos of duality differently from how it had been presented traditionally in the novel and in theatre. In the case of this novel too we can speak of "theatralization," "dramatization".

Polyphony is theatralization to a maximum degree. And, in fact, in Bakhtin and Theatre a major "justification” for relating Bakhtin to Konstantin Stanislavsky, Vsevolod Meyerhold and Jerzy Grotowski is Bakhtin's vision of Dostoevsky's polyphonic novel. Under this respect, of particular interest in McCaw's book are the paragraphs: "Dostoevsky and theatre," "Hero in Dostoevsky," "Dialogue in novel, theatre and life," "Time, space and the chronotope in novel and theatre", "Masks of the rogue, the clown and the fool", "Carnival and theatre" (McCaw, 2016, pp. 39-56). Most significant is reference to that popular comical-satirical genre known as "Menippean satire" that Bakhtin derives from the carnivalesque tradition (pp. 42-44).

Viewed through McCaw's readings of Bakhtin's works, it would seem that Dostoevsky too was involved in theatrical discourse. Because of the special form of dramatization he invents through recourse to polyphony, though a master of the novelistic genre, Dostoevsky's artworks could even be described in terms of "metatheatre" more than "metanovel".

McCaw refers to Bakhtin's works in English translation: Problems of Dostoevsky's Poetics, but also (especially for the Bakhtinian conception of the author-hero relation), The Dialogic Imagination, Speech Genres and Other Late Essays, "Author and Hero in Aesthetic Activity," Toward a Philosophy of the Act; an important role is attributed to Bakhtin's Rabelais and His World. Bakhtin's focus on the carnivalesque provides McCaw with arguments that support the connection he establishes between Bakhtin and these three artists of the theatre.

In his introduction, "Methodology: questions, images and dialogue," McCaw (2016, p. 2) also refers to Roland Barthes, specifically to the 1982 essay collection L'ovvie et l'obtus (The obvious and the obtuse). In the language of geometry, the obtuse angle is an open angle by comparison to the 
Figure 2. Konstantin Stanislavsky

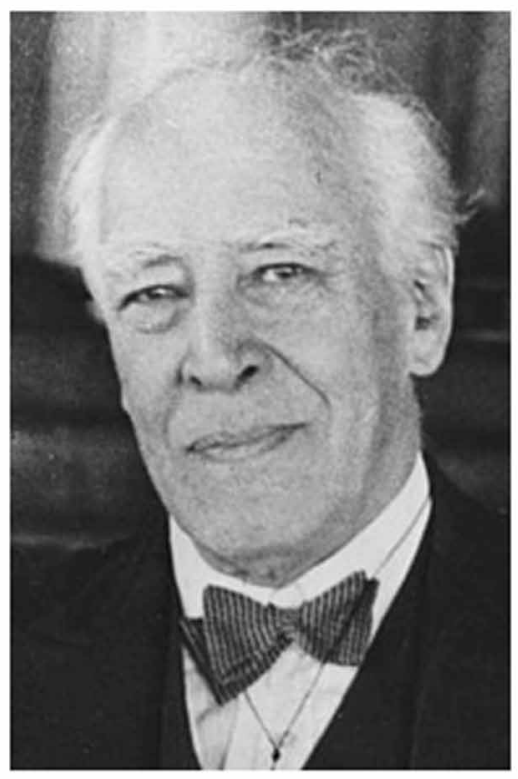

acute angle and the right angle: metaphorically, the obtuse angle indicates "hospitality," "responsive understanding" ("answering comprehension"), to use an expression introduced by Bakhtin. "Obtuse" also signifies "stupid". In the carnivalesque topsy-turvy world of folklore and popular fables, the idiot is the character who ends up solving problems that seemed unsurmountable.

Given Bakhtin's close relations with members of the Bakhtin Circle, McCaw's comparison between Bakhtin and Stanislavsky, Meyerhold and Grotowski involves the works of these authors as well, and not only those signed by Bakhtin. Reference here in particular is to the works of major expondents of the so-called Bakhtin Circle such as Pavel N. Medvedev, author of Formal'nyj metod $v$ literaturovedenii (1928), and Valentin N. Vološinov, author of Frejdizm (1927) and Marksizm $i$ filosofija jazyka (1929). Lev Pumpiansky is another Bakhtinian taken into consideration by McCaw.

In addition to the secondary literature on Bakhtin and his Circle authored by Craig Brandist, Katerina Clark, Carly Emerson, Michael Holquist, Gary Saul Morson, Tzvetan Todorov, McCaw evokes the work of other theatre directors such as Bertold Brecht and Eugenio Barba, as well as other scholars (somehow related to Bakhtin's work) who shed light on the themes under analysis. These include Lev Vygotsky, Viktor Shklovsky, Maurice Merleau-Ponty, Jean-Paul Sartre and Martin Buber. William Shakespeare is also invested with a significant role in McCaw's book.

Central themes orienting his research in Bakhtin and Theatre, listed in his introduction, include: "time and space," "body and image," "character and author," "realism and revolution" - consider the socio-political events on the background of Bakhtin's works -, "art and life". "Part I" is dedicated specifically to the relation between Bakhtin (and his Circle) and theatre with special reference to his works on Dostoevsky and Rabelais; "Part II" relates Bakhtin to Stanislavsky; and "Part III" relates Bakhtin to Meyerhold and Grotowski. A fundamental thesis developed by McCaw is that "Bakhtin's ideas about the novel can illuminate questions that are central to theatre," and vice versa problems of the theoretical and practical orders relating to theatre serve "to test some of Bakhtin's ideas about dialogue in everday life and dialogue in the novel" (2016, p. 59). 


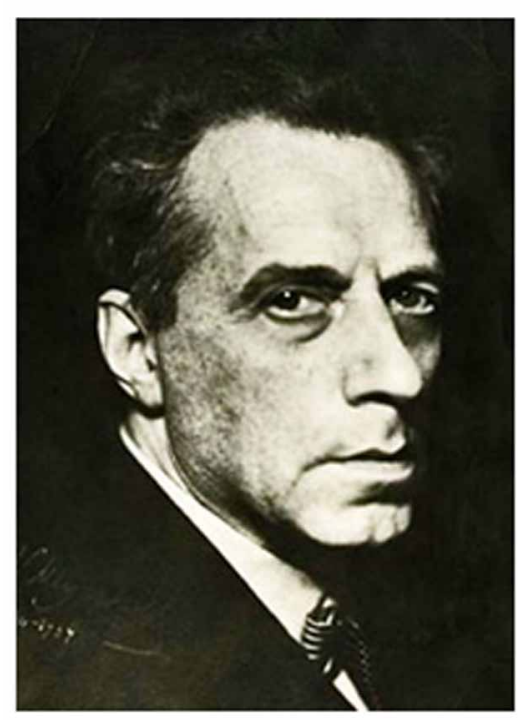

\section{NOVEL, THEATRE AND LIFE}

Bakhtin's writings shed light on the work of the three theatre directors under consideration and on theatrical works, on dramatic genres generally. The opposite is also true, no doubt, but on this account deeper insights into Bakhtin's ideas are relevant insofar as they contribute to a better understanding of theatrical genres. For somebody like me interested in Bakhtin, this is a great merit of McCaw's book.

Studies on the novelistic genre, on the word in the novel, Bakhtin's life-long interest, also benefit from McCaws comparative study. The novel's specificity emerges even more clearly when related to theatrical genres considered from a Bakhtinian perspective. This study also sheds light on what Bakhtin calls the process of "novelization," on how the novel, including in its "polyphonic bend", has influenced, or could potentially influence, theatrical genres.

We should not forget that Bakhtin neither considered himself to be a "philologist" nor a "literary critic," as he declared two years before his death, in his 1973 conversations with Viktor Duvakin: "I'm a philosopher, I always have been and always will be". Overall Bakhtin's writings are philosophical, pertaining particularly to "moral philosophy," even when he focuses on literary writing, on Dostoevsky's works, through which he evidences how the life of each one of us is inexorably implicated in the life of every other; as well as on Rabelais's works, through which he juxtapposes today's individualistic and egocentric vision of the world to ancient forms of popular culture where each single individual experiences his own body in a relationship of involvement with the body of others insofar as they are living bodies, whether human or nonhuman, plant life included. The socalled "grotesque body," thus denominated by Bakhtin, plays an important role in the multiform manifestations of popular culture, influencing the historical configuration of theatrical genres as much as the novel in its polyphonic form.

Bakhtin makes his first appearance in 1919, with his article "Art and Answerability" (in Bakhtin, 1990, pp. 1-3). This was followed by an essay from the twenties, published in English translation as Toward a Philosophy of the Act (Bakhtin, 1993). In Bakhtin and Theatre, McCaw reads the whole course of Stanislavsky's works - his theatre productions and his written texts, including his autobiography My Life in Art, and An Actor's Work (a book in two volumes unpublished during his lifetime) - in the light of these early writings by Bakhtin, and specifically his studies on ethics and 
aesthetics, Toward a Philosophy of the Act and "Author and Hero in Aesthetic Acitivty". From different persepctives, Bakhtin and Stanislavsky both focus on the interconnection between art and life.

According to Bakhtin, the task of moral philosophy is to describe the concrete architectonics of the actual, real world of the performed act; not the abstract scheme, but the concrete plan of the world of the unitary and singular act. In the following passage from Toward a Philosophy of the Act, Bakhtin describes the fundamental moments of the act, their mutual arrangement in the construction of the act. His reflections evidence the broad scope of his vision and the centrality of the notion of the act in his moral philosophy:

These basic moments are I-for-myself, the other-for-me, and I-for-the-other. All the values of actual life and culture are arranged around the basic architectonic points of the actual world of the performed act or deed: scientific values, aesthetic values, political values (including both ethical and social values), and, finally, religious values. All spatial-temporal values and all sense-content values are drawn toward and concentrated around these central emotional-volitional moments: I, the other, and I-for-the-other. The first part of our inquiry will be devoted to an examination of these fundamental moments in the architectonic of the actual world of the performed act or deed-the world actually experienced, and not the merely thinkable world. The second part will be devoted to aesthetic activity as an actually performed act or deed, both from within its product and from the standpoint of the author as answerable participant, and [2 illegible words] to the ethics of artistic creation. The third part will be devoted to the ethics of politics, and the fourth and final part to religion. (Bakhtin, 1993, pp. 53-54)

In his 1919 article, "Art and answerability", a sort of programatic text, a "manifesto" for his ensuing research, Bakhtin describes two worlds, the unofficial world of lived experience and the official world of culture, of the social. The "unofficial world" gives expression to the singularity, the uniqueness, the otherness of each person, participative and unindifferent to the otherness of others; instead, the "official world" of the social is made of relations among identities, roles, individuals, defined and classified on the basis of coordinates that assume these identities, these roles and individuals as representatives of a class, system, agglomeration of some sort. "Representatives" are indifferent to each other, in other words, they partake in relations among differences that are indifferent to each other (see Petrilli, 2014b; Petrilli \& Ponzio, 2003; Ponzio, 2002). What Bakhtin describes is, on the one hand, the singularity, the unreplaceability of each one of us, the specificity of one's own special relations, experiences, spatio-temporal and axiological coordinates; and, on the other, relations of exchange among individual representatives of a group, system, class, role, community, collective of some sort.

In "Art and Answerability" Bakhtin evidences how to fully live out the significance of life and the vitality of art requires just this: that we recognise how art and life are connected on the basis of the otherness relationship, which involves recognizing the singularity of each one of us, in relations of unindifference of one to the other. Unity among the constitutive elements of the human personality is guaranteed by answerability, that is, responsibility/responsiveness: "I have to answer with my own life for what I have experienced and understood in art, so that everything I have experienced and understood would not remain ineffectual in my life" (in Bakhtin, 1990, p. 1). And continuing:

Nor will it do to invoke "inspiration" in order to justify want of answerability. Inspiration that ignores life and is itself ignored by life is not inspiration but a state of possession. The true sense, and not the self-proclaimed sense, of all the old arguments about the interrelationship of art and life, about the purity of art, etc. - that is, the real aspiration behind all such arguments - is nothing more than the mutual striving of both art and life to make their own tasks easier, to relieve themselves of their own answerability. For it is certainly easier to create without answering for life, and easier to live without any consideration for art. 
Art and life are not one, but they must become united in myself - in the unity of my answerability. (p. 2).

Though relegated to the private sphere the single individual's otherness, uniqueness, and participative involvement, unindifference to the other, to the other's singularity subtend official life, the social, the cultural, the public, the conventional with their relative roles and responsibilities, formal responsibilities, responsibilities limited by alibis: it is thanks to the other who turns towards me and demands an attitude of "responsive understanding," that I too appear unique, unreplaceable, responsible without the possibility of resorting to alibis (see Petrilli, 2016a, pp. 195-217, pp. 222-225).

On Bakhtin's account, to invest the existence of each living being with purely formal, technical value as established by law, as though the law had a will of its own, leaving aside the singularity of the unique event, can generate irresponsibility and devastation. In Toward a Philosophy of the Act, Bakhtin compares abstract cognition to technological progress:

The detached content of the cognitional act comes to be governed by its own immanent laws, according to which it then develops as if it had a will of its own. Inasmuch as we have entered that content, i.e., performed an act of abstraction, we are now controlled by its autonomous laws or, to be exact, we are simply no longer present in it as individually and answerably active human beings.

This is like the world of technology: it knows its own immanent law, and it submits to that law in its impetuous and unrestrained development, in spite of the fact that it has long evaded the task of understanding the cultural purpose of that development, and may serve evil rather than good. Thus instruments are perfected according to their own inner law, and, as a result, they develop from what was initially a means of rational defense into a terrifying, deadly, and destructive force.

All that which is technological, when divorced from the once-occurrent unity of life and surrendered to the will of the law immanent to its development, is frightening; it may from time to time irrupt into this once-occurrent unity as an irresponsibly destructive and terrifying force. (Bakhtin, 1993, p. 7)

The official, formal, general, universal all acquire sense and value beginning from singularity, from the single individual's unique place in the world. Recognition of singularity, of "non-alibi in existence" invests the general with sense and value: "Non-alibi" means "without excuses," "without escape"; and it also means the "impossibility of being elsewhere" with respect to the place that only the unique, singular being can occupy in life: the spatio-temporal and axiological "architectonics" of the single individual in one's uniqueness confers sense and value upon abstract identity, upon the individual in one's social role, as a representative of a group, class, concept, as the member of a given community, with limited responsibilities and alibis:

What underlies the unity of an answerable consciousness is not a principle as a starting point, but the fact of an actual acknowledgment of one's own participation in unitary being-as-event, and this fact cannot be adequately expressed in theoretical terms, but can only be described and participatively experienced. Here lies the point of origin of the answerable deed and of all the categories of the concrete, once-occurrent, and compellent ought. I, too, exist [et ego sum] actually - in the whole and assume the obligation to say this word. I, too, participate in being in a once-occurrent and never repeatable manner: I occupy a place in once-occurrent Being that is unique and never-repeatable, a place that cannot be taken by anyone else and is impenetrable for anyone else. In the given onceoccurrent point where I am now located, no one else has ever been located in the once-occurrent time and once-occurrent space of once-occurrent being. And it is around this once-occurrent point that all once-occurrent being is arranged in a once-occurrent and never-repeatable manner. That which can be done by me can never be done by anyone else. The uniqueness or singularity of present-onhand Being is compellently obligatory. 
This fact of my non-alibi in Being, which underlies the concrete and once-occurrent ought of the answerably performed act, is not something I come to know of and to cognize but is something I acknowledge and affirm in a unique or once-occurrent manner. (p. 40)

According tp McCaw, to establish a relation between art and life in Bakhtin's case means to create a verbal image of a person's life; in Stanislavsky's case it means to enter the mind of a character and bring this verbal creation to life on stage (McCaw, 2016, p. 64). As evidenced in the title itself of his autobiography, My Life in Art, Stanislavsky too searches for life in art, specifically in the art of acting - and acting is good when it is alive: "This sense of the live-ness of good acting constituted his definition of what is 'real' and defines Stanislavsky's revolution in the art of acting," as McCaw claims (p. 65).

What unites the art-world and the life-world is not technical or formal responsibility, but moral responsibility, responsibility without alibis, connected to the unique event of the singular, participative, unindifferent act (see Petrilli 2012a, 2012b, 2012c). In Bakhtin's phenomenology, centrally important is the concept of "event" (in Russian sobytie). Referred both to the act and to the literary work, the event can be connected to experience and value. The sense of the event, as McCaw says, renders an act or its representation "real" in a phenomenological sense: a performance is an event involving two groups of participators, on the side of the actor and of the public; a performance perceived and actualised through bodily experience rather than through intellectual reflection.

The political context at the time Bakhtin was writing his early texts and Stanislavsky was working on his own texts was marked by epochal transformations: the birth of the Soviet Union, Lenin's death in 1924, the ensuing struggle among the Bolsheviks, ending only in 1928 with Stalin's rise to power. In 1929, Bakhtin was arrested for religious activities. In 1930 he was taken to trial and condemned to exile. Valentin N. Vološinov, a major exponent of the Bakhtin Circle, author of Marxism and the Philosophy of Language, 1929, in which he underlines the need for studies in Marxist circles on problems of language and ideology, died in 1936. The Stalin purges began in 1937 and Bakhtin's friend and collaborator, Pavel Medvedev, author of The Formal Method in Literary Scholarship, 1928, was also arrested and soon after (17 July 1938) executed by a firing squad. After his arrest in 1939, Meyerhold, whom Stanislavsky considered his only heir, was tortured and executed (February 1940). Both Bakhtin and Stanislavsky suffered the effects of Stalinist repression during the most creative years of their intellectual production: the 1920s and 1930s were central years in Bakhtin's life and coincided with the final creative phase in Stanislavsky's life, when he focused on his "Method of Physical Actions" and on his book, An Actor's Work.

Bakhtin refers to Stanislavsky's theatre production in his notes of the 1970s: "Stanislavsky on the beauty of play - the actor's depiction of a negative image. Mechanical division is unacceptable: ugliness - a negative character, beauty - a performing actor" ("From Notes Made in 1970-71," in Bakhtin, 1986, p. 155). Stanislavsky's theatre validates Bakhtin's theory on the essential unity between art and life, thematized in his philosophical writings. Mechanical acting is acting unresponsive to life, acting without the body, without imagination, repetetive and indifferent to the other: this was a central concern in Stanislavsky's theatre works and one which Bakhtin developed in the philosophical sphere.

McCaw believes that Stanislavsky's reflections resound in Bakhtin's when the former maintains that "there are positive things hidden among negative phenomena" and that "there is an element of beauty even in the most ugly, just as the beautiful contains things which are not beautiful" (An Actor's Work, as cited in McCaw, 2016, p. 68); and Bakhtin claims that the specificity of the artistic vision is given by the capacity to love: "in aesthetic seeing you love a human being not because he is good, but, rather, a human being is good because you love him. This is what constitutes the specific character of aesthetic seeing" (Bakhtin, 1993, p. 62; see also Petrilli \& Ponzio, 2014). Both Bakhtin and Stanislavsky evidence the aesthetic productivity of love. In fact, for Bakhtin the condition for aesthetic creation is love, love renders the ugly beautiful. Love even renders the hateful lovable, as the American philosopher and semiotician Charles Sanders Peirce (1839-1914) had also claimed with 
his evolutionary philosophy: "growth comes only from love, [...] from the ardent impulse to fulfill another's highest impulse. [...] Love, recognizing germs of loveliness in the hateful, gradually warms it into life, and makes it lovely" (Peirce, 1931-1958, para. 6.289; see also Petrilli, 1990b, 1993, 2010).

But to return to Bakhtin and Stanislavsky, though their views on aesthetic creation can be related, there are significant differences. With respect to Bakhtin, Stanislavsky's perspective changes insofar as he turns his attention to the actor/artist who must create the character, a fully rounded character, and not just a stereotype: "You love yourself in the role more than the role in you. [...]. Learn to love the role in yourselves" (McCaw, 2016, p. 68). And while for Bakhtin it is the author who leads the game, for Stanislavsky it is the actor: "The author's creative work ends with a finished character, the very point where the actor's creative work begins" (pp. 68-69).

In light of the connection between art and life, both Bakhtin and Stanislavsky analyze the relation between character and living person, and between character and author, distinguishing between theatrical character, the actor/artist, and the character in literary writing, the hero, and again between the character and the reader/audience (see Petrilli, 2015b; Petrilli \& Ponzio, 2006, 2016). The notions of character, action/act, event, I and other, authoriality, value, responsibility, responsiveness are all centrally important in Bakhtin and Stanislavsky. Among the themes that unite these two authors beyond those already mentioned: the question of the chronotope, of time and space in the novel and in theatre, the role of experience by contrast with the life of reflection, the given and the created, value, sense, meaning and significance, corporeality, the internal and the external image, creativity, the unconscious.

\section{BAKHTIN IN POLYPHONIC DIALOGUE WITH STANISLAVSKY, MEYERHOLD AND GROTOWSKI}

The ideal "dialogue" established by McCaw between Bakhtin and Stanislavsky, Meyerhold and Grotowski in Bakhtin and Theatre involves positions that are very different, and under certain aspects even opposed to each other. Moreover, as portrayed in this well-documented book, the real dialogue among the three theatre directors evidences how each one of them these is innovative, sui generis to the point of breaking with each other, but always in relations of continuity, offering an extraordinary example of "polyphony" in the terms theorized by Bakhtin.

While Stanislavsky's ideas, his overall project can be read in the light of Bakhtin's early writings, Meyerhold's work resonates with ideas elaborated by Vološinov and Medvedev in the 1920s, and by the later Bakhtin. The relationship between Meyerhold and Stanislavsky developed across different phases as the two men sometimes agreed with each other and other times clashed, driven at once by shared interests and profound divergences. Their dialogue evolved from their common love for theatre, oriented in directions that were altogether different, even diametrically opposed in terms of the philosophy, aesthetics and pedagogy animating their respective visions (pp. 149-150). In any case, their relationship was always intense, mutually participative and challenging - the creative encounter of a life-time.

If like Stanislavsky, Meyerhold too aimed to elevate theatre to the status of an art in its own right - Bakhtin speaks of "art theatre" for the type of theatre he enjoyed -, unlike Stanislavsky, Meyerhold identified the truth of theatre in "theatricality". Meyerhold was fascinated by the "Commedia dell'Arte" and by popular traditions. He was interested in the specificity of theatrical signification: theatre must be theatrical. On the contrary, Stanislavsky rejected "theatricality," considering it a negation of theatre.

According to Meyerhold, in "theatrical theatre" the audience must not forget that the actor is acting, just as the actor must not forget that he is in a theatre, on a stage (Meyerhold in McCaw, 2016, p. 149). His vision of the "theatrical theatre" led him to reject the "literary tendency" characteristic of the Moscow Art Theatre. Instead, Stanislavsky chose to bring the The Bluebird by Maurice Maeterlinck (Nobel laureate for literature) to the theatre (see Petrilli 2015c, 2016, pp. 233-258); and Nemirovich-Danchenko adapted Dostoevsky's novel The Brothers Karamoz to the stage. 
In MacCaw's interpretation Meyerhold reverses Bakhtin's conception of the novelization of theatre and maintains that Dostoevsky should be considered a dramatist. Meyerhold opened the stage to the audience, extending it into the auditorium, consolidating a practice that seemed to contradict Bakhtin's vision of theatre as a closed genre. However, Meyerhold and Bakhtin were in accord on certain issues: they both evidenced the relation of theatre to popular culture; and they both drew on images from popular theatre via the mediation of Puškin who also asserted the popular tradition. In McCaw's view: "Meyerhold's revolution in theatre involved him rejecting the realist assumptions that provided a common ground between Stanislavsky and Bakhtin" (p. 150). "Revolution" for Meyerhold meant rejecting realist assumptions; instead for Stanislavsky and Bakhtin they were connected.

Like Bakhtin, both Stanislavsky and Meyerhold were preoccupied with the question of time. Bakhtin had focused on the question of the "chronotope," a space-time paradigm for human time and history, which he applied to literary genres, particularly the novel, from the very beginning of his research itineraries.

As he recounts in a note to his essay "Forms of Time and of the Chronotope in the Novel. Notes Toward a Historical Poetics" (in Bakhtin, 1981, pp. 84-258), Bakhtin in the summer of 1925 attended a lecture on the chronotope in biology by the physiologist A. A. Ukhtomsky. Bakhtin of course was interested in the chronotope relatedly to aesthetics, an aspect Ukhtomsky also touched upon. As Bakhtin observes:

We will give the name chronotope (literally "time space") to the intrinsic connectedness of temporal and spatial relationships that are artistically expressed in literature. [...] What counts for us is the fact that it expresses the inseparability of space and time (time as the fourth dimension of space). We understand the chronotope as a formally constitutive category of literature. (p. 84)

Though Bakhtin, Meyerhold and Stanislavsky all pay special attention to the question of rhythm, Meyerhold's perspective was significantly different: for Meyerhold rhythm was related to "a musical conception of performance time," time concerns acting; instead, for Stanislavsky and Bakhtin it concerns "the double structure of narrative time" (McCaw, 2016, p. 150).

Like Stanislavsky Jerzy Grotowski also aimed to "revolutionise the theatre itself" (in Kumiega, 1985, p. 83, as cited in McCaw, 2016, p. 184), constantly questioning its sense and purpose. Grotowski distinguished between "theatre as form and acting as an activity," the guiding theme of McCaw's book (2016, p. 184). Like Stanislavsky and Meyerhold, Grotowski engaged in creating a new type of theatre, thus a new type of actor for his productions. To this end he dedicated an important part of his attention to actor training and relative teaching methodologies. According to McCaw, this explains the symbiotic relationship between Grotowski the actor-trainer and Grotowski the director. Grotowski was not interested in training actors according to a fixed system, as though to provide them with a "theatrical toolkit" (p. 185). Rather than teach acting his intent was to work on the actor and with the actor in order to achieve the "total act," which meant to develop the most subtle nuaces of the inner life within the framework of the role (Grotwski in Hodge, 2000, 193, as cited in McCaw, 216, p. 185).

McCaw evidences the contact points between Grotowski and Bakhtin, for example, they both start from the same image of "incompleteness" and for both the concept of "act" is central. All the same, despite points of contact McCaw shows how Bakhtin and Grotowski take different directions and present significant variations: in Bakhtin's vision, for example, the problem of "incompleteness," "unfinalizability" is a positive human condition which distinguishes the character of the polyphonic novel; instead, for Grotowski the greatest achievement at theatre was to accomplish the "total act". The "total act" means to transcend incompleteness, therefore it means to overcome separation between thought and feeling, thought and perception, body and soul, consciousness and the unconscious, seeing and instinct, sex and reason (Grotowski in Kumiega, 1985, pp. 128-129, as cited in McCaw, 2016, p. 185).

For Grotowski, the problem of the relation between art and life is centrally important. However, whilst Bakhtin, Stanislavsky and Meyerhold deal with the issue in theoretical terms, Grotowski makes it a practical concern: theatre is life, the actor must develop instruments and skills to access 


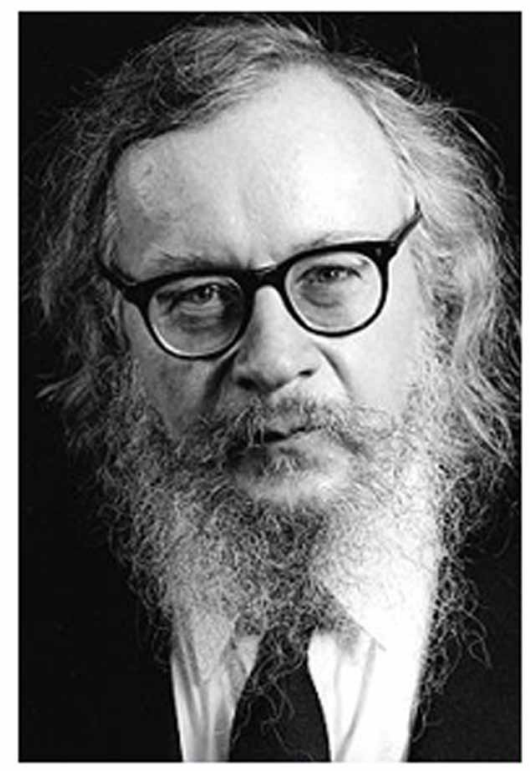

one's own creativity, humanity and thus overcome the limitations of one's own self in the encounter with the other, with life.

Whilst Stanislavsky worked on role, Grotowski privileged physical actions leading to the actors work on his inner self. Like Stanislavsky and Meyerhold, Grotowski engaged in situating his work in relation to art and life, but unlike his predecessors, as McCaw says, "his project, firstly in the Theatre of Productions but more obviously in the Theatre of Participation, aimed to collapse these two categories," for in Grotowski's theatrical productions "aesthetic means are developed in order to work on oneself," and this meant one's body (p. 186).

Grotowski's "Theatre of Participation" projects theatricality as encounter and as a means to reconnect with life, to rivitalise, regenerate life itself. Moreover, given the positioning of theatrical performance in time, that is, in the present moment, acting provided a model for the relation between actor and audience, "a conflation of art and life" (p. 187): the aesthetic and the ethical, form and experience, art and life in Grotowski "become one" (p. 191).

Grotowski was interested in actor training and, as he recounts in his book Towards a Poor Theatre, 1991, he assumed the Bohr institute as the model of reference for his laboratory. Like Stanislavsky and Meyerhold, Grotowski also believed that research connected with theatre should be scientific and methodologically rigorous. Bakhtin and his friends Medvedev and Vološinov could only agree, but without reducing the art of theatre to a scientific discipline, as rightly observed by McCaw (pp. 191-192; also Petrilli, 1992, 2014c, 2015a).

Grotowski's approach to actor training is characterized by the two Latin expressions: via negativa and conjunctio oppositorum. Paradoxically, training as an actor involved getting rid of old habits, more than learning new skills (cf. Grotowski, 1991, pp. 17, 96-97, 177, as cited in McCaw, 2016, p. 192). For Grotowski the actor's creativity was a negotiation between form and experience: "Creativity, especially where acting is concerned, is boundless sincerity, yet disciplined: i.e. articulated through signs. [...] And as the actor's material is his own body, it should be trained to obey, to be pliable [...] it does not offer resistance. Spontaneity and discipline are the basic aspects of an actor's work and 
they require a methodical key" (p. 193). The tension between the "objective elements" and "purely subjective" work, according to Grotowski, is the "contradiction of acting" and the "kernel of training".

McCaw points out how the relation between I and other is central in both Bakhtin and Grotowski, once again however their perspectives are different. Grotowski highlights the multiplicity of selves that constitute the I's identity, the actor's identity. According to Grotowski, through dialogue with the character as other to himself, the actor is able to identify his own I (or "Ident" to use a neologism introduced by the English philosopher of language, Victoria Lady Welby, see Petrilli, 1990a; 2009, pp. 640-670; 2016a, pp. 172-174). Contrary to Bakhtin and Stanislavksy, for Grotowski the character is not another human being, another identity, with a life of one's own. As McCaw observes, the other is not the other in Bakhtin's sense, the enabling other. Rather, in Grotowski's case the other is an instrument, a means for the actor to reach self-discovery and can even be the image of another person from a different epoch. The actor encounters the character: in other words, rather than illustrate Hamlet, the actor must meet him (McCaw, 2016, pp. 200-201).

Unlike Bakhtin, Grotowski is concerned with the actor's identity more than the character's identity and claims (with an image that, according to McCaw, evokes Antonin Artaud's "cruel theatre") that the actor must use his role like a surgeon's scalpel, to dissect oneself. Though actors work on their characters not to torture them, but to discover their own true identity (Grotowski, 1991 p. 88, as cited in McCaw, 2016, p. 2000; Petrilli, 2003).

Freed of the social, of the imagination, of one's masks - "life-masks," which Grotowski associates to superficiality and deception -, the individual approaches truth, one's own true self. Therefore, in the relation to one's audience, as part of a process of exteriorization of one's own self, the task of the actor is to reveal himself, not in the sense of exhibitionism, showing off, but rather in the sense of revelation (cf. p. 201). Grotowski's aesthetics is subject to an ethical demand: the actor strips himself of his inauthentic social masks through a public act of self-revelation.

The relation between actor and audience is central in Grotowski's definition of theatre. It subtends his approach to theatre and his eventual abandonment of theatre (cf. p. 210). A complex of three relations characterizes his conception of theatrical space and relations: actor-director; actor/directorcharacter; actor-audience. According to McCaw: "Bakhtin and Stanislavsky both considered that a character had a relation to a human being," and "this relation between the actor/author and the character included degrees of empathetic identification and aesthetic distance". Instead, Meyerhold considered the character in almost sculptural terms: depending on corporeality, physicality, voice, movement, the actor would be considered suitable or not for a given range of roles. In Bakhtin, Stanislavsky and Meyerhold, the character has content and is endowed with features that are recognizable for the audience. Instead, for Grotowski the character is a means through which the actor comes to know himself and can reveal himself to the audience hic et nunc (here and now): “'Selves' and 'roles' we construct through our social development are rejected as inauthentic masks that have to be removed to access the underlying true self. Grotowski rejects the possibility or value of understanding oneself as a character."

In "Forms of Time and of the Chronotope in the Novel," Bakhtin proposes an opposite strategy which consists in putting on the mask, rather than tearing it off (pp. 200-201). Masks have deep roots in popular culture and are endowed with extraordinary significance. With special reference to three figures - the rogue, the clown and the fool -, Bakhtin describes the connection between the characteristic masks of popular culture, masks populating the public square, on one hand, and masks of the public spectacle and theatre, theatrical masks, on the other. Moreover these masks, as Bakhtin says, do not have a "direct, but rather a metaphorical, significance" (Bakhtin, 1981, p. 159), indeed "their existence is a reflection of some other's mode of being - and even then, not a direct reflection. They are life's maskers; their being coincides with their role, and outside this role they simply do not exist." Bakhtin elaborates on the metaphor of the mask to thematize the I-other relation and one's right to otherness, to extraneousness, strangeness, to what we can also call "extracommunitariness" (Petrilli, 2013, pp. 147-160, 200-219): 
Essential to these three figures is a distinctive feature that is as well a privilege - the right to be "other" in this world, the right not to make common cause with any single one of the existing categories that life makes available; none of these categories quite suits them, they see the underside and the falseness of every situation. Therefore, they can exploit any position they choose, but only as a mask. (Bakhtin, 1981, p. 159)

Though united in their common effort to recognise the gap between the social mask and "authentic" identity, Bakhtin and Grotowski elaborate visions and methodologies that are altogether different: Grotowski believes that one must rip off one's masks to reach the true self, the real, authentic self; Bakhtin resorts to the opposite strategy and searchs for sense and meaning in the play of masks, in the condition of dialogism that this play of masks evidences. For Bakhtin identity is constituted in the relation among multiple masks, in the intercorporeal relation between I and other:

In the struggle against conventions, and against the inadequacy of all available life-slots to fit an authentic human being, these masks take on an extraordinary significance. They grant the right not to understand, the right to confuse, to tease, to hyperbolize life; the right to parody others while talking, the right to not be taken literally, not "to be oneself"; the right to live a life in the chronotope of the entr'acte, the chronotope of theatrical space, the right to act life as a comedy and to treat others as actors, the right to rip off masks, the right to rage at others with a primeval (almost cultic) rage-and finally, the right to betray to the public a personal life, down to its most private and prurient little secrets (Bakhtin, 1981, p. 163).

Unlike Bakhtin, in Grotowski dialogue is monological, a unidirectional and univocal exchange, that neither calls for a response from the other, nor expects it (McCaw 2016, p. 202). However, in a subsequent phase of his work and without giving up the de-masking metaphor, Grotowski like Bakhtin no longer insists on the character as an instrument, a means to knowing one's own true identity. Instead, he too interprets identity in terms of the relation with the other, in the terminology of the French philosopher Emmanuel Levinas, with "the other man," as recites the title of his 1972 book, Humanisme de l'autre homme (Humanism of the other man). Grotowski ends up valorizing the actor not for acting for the audience, but for encountering the other.

Grotowski was interested in theatre as a system of signs, which revealed the human personality and which he identified in the body, sound, voice, image, gesture and movement more than in the verbal sign. He became ever more critical of verbal communication and the play of forms. Against fear provoked by the absence of sense, Grotowski advised the via negativa: it was necessary to unmask onself, to disarm. McCaw (2016, p. 209) cites Grotowski from Schechner e Wolford (1997, p. 221): "We arm ourselves in order to conceal ourselves; sincerity begins where we are defenceless. Sincerity is not possible if we are hiding ourselves behind clothes, ideas, signs, productions, effects". Like Stanislavsky and Meyerhold, Grotowski emphasised the creative responsibility of the actor. However, the parametres of the actor's responsibility were defined by the director.

By contrast to Meyerhold's "Total Theatre," Grotowski's goal - as director, teacher in acting and author of montages, engaged in responding to the advance of technological sophistications and the expressive capacity of cinema and television - was the total act of the actor in a "Poor Theatre". This total act was achieved through the progressive shedding of all that makes theatre - no more setting, no more historical context, and no characters, no more theatrical means and conventions. All that remains is the simple fact of co-existence and the performance of actions: as anticipated, Grotowski effectively transits from making theatre to its abandonment.

Like Meyerhold before him in Russia, Grotowski also lived under a repressive regime, that of Polish communism. He was profoundly critical of the social which he refused with his conception of the post-theatre community, fully immersed in the hic and nunc, but separate from the inauthentic real world. Moving in this direction, Grotowski ended up rejecting theatre as a genre in favour of a 
new kind of interaction with people, made of co-existence, living together, actions, communion rather than communication, without narrations or images. In McCaw's interpretation, Grotowski rejected the optimistic social discourse of Medvedev and Vološinov, just as he rejected Bakhtin's notion of dialogism: "his point of connection with Bakhtin was in rooting his ideas in the body, but one that neither rejoices in nor acknowledges the material bodily lower stratum. It is a carnival of sorts, but without the laughter" (p. 211).

\section{CONCLUSION}

We will now conclude here our considerations on McCaw's analyses of Stanislavksy, Meyerhold and Grotowski and focus on Bakhtin. In fact, our interest in this essay from the very beginning is fundamentally Bakhtin. The same can be said of the author of the book we have been referring to. $\mathrm{He}$ in fact confronts perspectives, experiences and interests with Bakhtin that are distant from his research, but not extraneous to it.

Under this aspect, most interesting is that one of the last paragraphs in the conclusion to McCaw's book is entitled à la Bakhtin "Other, I and thou". In it, McCaw returns to the relationship between the I and the other as described by Bakhtin in his early writings, without failing to reference developments in his later research as well.

In Bakhtin dialogue is not so much a question of the exchange of rejoinders between an I and a you. Instead, Bakhtinian dialogue is tantamount to involvement, unindifferent participation with the other, co-implication, intercorporeality. It brings into play both voice and gesture. The constitutive multiplicity of the other's identity as much as of one's own, where the different voices do not converge with the $\mathrm{I}$, is best grasped through the gaze at a distance, through the eyes of the other. As Bakhtin observes in "Author and Hero in Aesthetic Activity" (1920-1924): "Ethical and aesthetic objectification requires a powerful point d'appui outside itself; it requires some genuine source of real strength out of which I would be capable of seeing myself as another" (Bakhtin, 1990, p. 31).

Bakhtin describes the otherness relationship in terms of mutual interdependency among voices and bodies and of mutual understanding and enhancement of sense. According to McCaw (2016, p. 230), "altruism" also comes into play here in addition to otherness. As observed by Bakhtin:

[...] one can speak of a human being's absolute need for the other, for the other's seeing, remembering, gathering, and unifying self-activity - the only self-activity capable of producing his outwardly finished personality. This outward personality could not exist, if the other did not create it: aesthetic memory is productive - it gives birth, for the first time, to the outward human being on a new plane of being. (pp. 35-36)

The other as understood by Bakhtin should neither be confused with Jacques Lacan's Other, nor with Tzvetan Todorov's interpretation of the other (1984), nor with Michael Holquist who calls on Martin Buber's ich und du. Bakhtin's "other" is neither "another I," "another myself" that differs relatively from me because, with respect to me, it bears the personal pronouns "he" or "she" or "it"; nor is it the subject of an address such as "you" or "thou." The other is other in itself, on its own account, independently and autonomously from the self, even if the other may appear to the self as an image: "the other person grasped visually or transformed into a verbal image" (McCaw, 2016, p. 231; see also Petrilli, 2018a, 2018b).

But the "other" is not only the other from me. The other is also the other of me, which I reach out to know and even control and govern, which comes to my consciousness, but which remains other, because the self of "coming to consciousness, to self-awareness" is other from the I, something different from the I.

As to the relation between novel and theatre, with Bakhtin we can make the claim that with respect to the novel, theatre is less capable of portraying the polyphony that resounds in the voice of 
the character. In the novel, specifically the polyphonic novel, multiple voices ring in the same word even. In this sense, we could claim that dialogue in the novel, as Bakhtin presents and proposes it, is theatrical dialogue more so than in theatre itself. This is because in Bakhtin's conception dialogue is capable of polyphony. And, in fact, à propos Bakhtin's interpretation of the character, McCaw (2016, p. 231) speaks of the "character as a voice", "a consciousness that answers for itself and by itself".

All the same, it should not be forgotten that in light of the relationship that Bakhtin establishes between art and life, art and responsibility, it is important not to identify with roles, masks, identities in the performance of life, the theatre of life. This orientation implies a relation of similarity between life and novel, above all in the form of the polyphonic novel; and, vice versa, a relation of difference between life and theatre, unless theatre too is novelized. To identify with roles, masks and identities means to take on the status of "representative" of a given social identity and to use one's status in a given role as an alibi, a pretext to evade the moral responsibility of the relationship between one singularity and another, that is, between one person and another each in one's own uniqueness, singularity. In other words, identification, self-identification, thus described means to use "representation" as an excuse to escape the face-to-face relationship, wherewith we become "impostors" or "pretenders" (cf. Petrilli, 2016a, pp. 264-277, 302-304). As Bakhtin writes in Toward a Philosophy of the Act:

In attempting to understand our whole life as secret representation and every act we perform - as a ritual act, we turn into impostors or pretenders.

Being a representative does not abolish but merely specializes my personal answerability. The actual acknowledgment-affirmation of the whole which I shall represent is my personally answerable act [...]. The same loss of once-occurrent unity takes place as a result of the attempt to see in every other, in every object of a given act or deed, not a concrete uniqueness which participates in being personally, but a representative of a certain large whole [...]

Life can be consciously comprehended only in concrete answerability. A philosophy of life can be only a moral philosophy. [...] A life that has fallen away from answerability cannot have a philosophy: it is, in its very principle, fortuitous and incapable of being rooted. (Bakhtin, 1993, pp. 52-53, 56) 


\section{REFERENCES}

Bachtin e il suo Circolo (2014). Opere 1919-1930 (A. Ponzio, Ed., Trans., Intro). Milan, Italy: Bompiani.

Bakhtin, M. M. (1929). Problemy tvorčestva Dostoevskogo. Leningrad, Russia: Priboj.

Bakhtin, M. M. (1963). Problemy poetiki Dostoevskogo [Problems of Dostoevsky's Poetics] (C. Emerson, Trans. \& Ed.). Minneapolis, MN: University of Minnesota Press. (Original work published 1929)

Bakhtin, M. M. (1965). Tvorčestvo Fransua Rable i narodnaja kul'tura srednevekov'ja i Renessansa. (H. Iswolsky, Trans. \& Ed.). Bloomington, IN: Indiana University Press.

Bakhtin, M. M. (1979). Voprosy literatury i estetiki (Problems of Literature and of Aesthetics). (C. Janovič, Trans.). Turin, Italy: Einaudi.

Bakhtin, M. M. (1981). The Dialogic Imagination. Four Essays (M. Holquist, Ed.) (C. Emerson \& M. Holquist, Trans). Austin, TX: University of Texas Press.

Bakhtin, M. M. (1986). Speech Genres \& Other Late Essays (V. McGee, Trans.), (C. Emerson \& M. Holquist, Eds.). Austin, TX: University of Texas Press.

Bakhtin, M. M. (1988). Estetika slovesnogo tvorcestva [Aesthetics of verbal art]. Moscow, Russia: Iskusstvo, 1979; L'autore e l'eroe. Teoria letteraria e scienze umana (C. Janovič, Trans.). Turin, Italy: Einaudi.

Bakhtin, M. M. (1990). Art and Answerability. Early Philosophical Essays by M. M. Bakhtin (M. Holquist \& V. Liapunov, Eds.), (V. Liapunov, Trans. \& notes), (K. Brostrom, Suppl. trans.). Austin, TX: University of Texas Press.

Bakhtin, M. M. (1993). Toward a Philosophy of the Act (1920-1924) (V. Liapunov, Trans. \& Notes), (M. Holquist \& V. Liapunov, Eds.). Austin, TX: University of Texas Press.

Bakhtin, M. M. (2008). Besedy V. D. Duvakina s M.M. Bachtinym, 1973. Moscow: Soglasie (1st ed. 1996); In dialogo. Conversazioni del 1973 con V. Duvakin (R. S. Cassotti, Trans.), (A. Ponzio, Ed.). Naples, Italy: Edizioni Scientifiche Italiane.

Barthes, R. (1982). L'obvie et l'obtus. Paris, France: Editions du Seuil.

Grotowski, J. (1991). Towards a Poor Theatre. London, UK: Methuen.

Hodge, A. (Ed.). (2000). Twentieth Century Actor Training. London, UK: Routledge.

Kumiega, J. (1985). The Theatre of Grotowski. London, UK: Methuen. doi:10.5040/9781472572165

Levinas, E. (1903). Humanisme de l'autre homme. Montepellier: Fata Morgana; Humanism of the Other Man (N. Poller, Trans.). Champaign, IL: University of Illinois Press.

McCaw, D. (2016). Bakhtin and Theatre. Dialogues with Stanislavsky, Meyerhold and Grotowski. London, UK: Routledge.

Medvedev, P. N. (1978). Formal'nyj metod v literaturovedenii. Leningrad; The Formal Method in Literary Scholarship: A Critical Introduction to Sociological Poetics (A. J. Wehrle, Trans.). Baltimore, MD: The Johns Hopkins University Press.

Peirce, C. S. (1958). Collected Papers of Charles Sanders Peirce (i 1866-1913), Vols. I-VI (C. Hartshorne \& P. Weiss, Eds.), 1931-1935, Vols. VII-VIII (A. W. Burks, Ed.). Cambridge, MA: The Belknap Press.

Petrilli, S. (1990a). Dialogue and Chronotopic Otherness: Bakhtin and Welby. Discours social/Social Discourse, 3(1/2), 339-350.

Petrilli, S. (1990b). The Problem of Signifying in Welby, Peirce, Vailati, Bakhtin. In A. Ponzio (Ed.), Man as a Sign (pp. 313-363). Berlin: Mouton de Gruyter.

Petrilli, S. (1992). The Detotalizing Method, Human Sciences and the Dialogic of Values. Social Semiotics, 2(2), 98-113. doi:10.1080/10350339209360362

Petrilli, S. (1993). Dialogism and Interpretation in the Study of Signs. Semiotica, 97(1/2), 103-118. 
Petrilli, S. (1996). Bachtin Read in Italy (1980-1994). Le Bulletin Bachtin The Bakhtin Newsletter, 5, 55-66.

Petrilli, S. (2003). Hamletism and Representation: Shakespeare, Laforgue, Artaud, Bene. In L. Block de Behar (Ed.), Between Myths and Knowledge (pp. 179-196). Montevideo, AILC/ICLA (Association Internationale de Littérature Comparée/International Comparative Literature Association).

Petrilli, S. (2009). Signifying and Understanding. Reading the Works of Victoria Welby and the Signific Movement (P. Cobley, Foreword, vii-x). Berlin: De Gruyter Mouton.

Petrilli, S. (2010). Sign Crossroads in Global Perspective. Semioethics and Responsibility (J. Deely, Ed.). New Brunswick, NJ: Transaction.

Petrilli, S. (2012a). Expression and Interpretation in Language (V. Colapietro, Preface, xi-xiii). New Brunswick, NJ: Transaction.

Petrilli, S. (2012b). Altrove e altrimenti. Filosofia del linguaggio, critica letteraria e teoria della traduzione in, intorno e a partire da Bachtin. Milan: Mimesis.

Petrilli, S. (2012c). Un mondo di segni. L'avere senso e il significare qualcosa. Bari, Italy: Edizioni Giuseppe Laterza.

Petrilli, S. (2013). The Self as a Sign, the World, and the Other. Living Semiotics (A. Ponzio, Foreword, xiii-xvi). New Brunswick, NJ: Transaction.

Petrilli, S. (2014a). Riflessioni sulla teoria del linguaggio e dei segni. Milan, Italy: Mimesis.

Petrilli, S. (Ed.). (2014b). Semioetica e comunicazione globale. Milan, Italy: Mimesis.

Petrilli, S. (2014c). Sign Studies and Semioethics. Communication, Translation and Values. Berlin, Germany: De Gruyter Mouton.

Petrilli, S. (2015a). Nella vita dei segni. Percorsi della semiotica. Milan, Italy: Mimesis.

Petrilli, S. (2015b). Representation and Literary Writing. From Identity to Alterity: Re-writing and De-writing Shakespeare with Laforgue and Bene. Foreign Literature Studies, 6, 46-58.

Petrilli, S. (2015c). Human Life, Symbol and Writing. Maurice Maeterlinck's L'Oiseau blêu. Chinese Semiotic Studies, 11(1), 39-64. doi:10.1515/css-2015-0002

Petrilli, S. (2016a). The Global World and Its Manifold Faces. Otherness as the Basis of Communication. Berne, Switerzland: Peter Lang.

Petrilli, S. (2016b). Mikhail Bakhtin and his circle. Works 1919-1930 [Michail Bachtin e il suo circolo. Opere 1919-1930] Book Review. [Editor-in-Chief I. Klyukanov. Routledge, UK: Taylor and Francis Group.]. Russian Journal of Communication, 8(1), 1-6.

Petrilli, S. (2016c). Dialogue, responsibility and literary writing. Mikhail Bakhtin and his Circle. Semiotica, 213(1/4), 2016.

Petrilli, S. (2017). Lifelong Listening to M. Bakhtin's Word in the Context of His "Circle". A Philological Approach by A. Ponzio. Philology. An International Journal on the Evolution of Languages Cultures and Texts, 3, 361-395.

Petrilli, S. (Ed.). (2018a). L'immagine nella parola, nella musica e nella pittura. Milan, Italy: Mimesis.

Petrilli, S. (2018b). Vision of the Other: Word and Image in Mikhail Bakhtin. International Journal of Semiotics and Visual Rhetoric, II(1), 120-136.

Petrilli, S., \& Ponzio, A. (2003). Semioetica. Rome, Italy: Meltemi.

Petrilli, S., \& Ponzio, A. (2005). Semiotics Unbounded. Interpretive Routes in the Open Network of Signs. Toronto, Canada: Toronto University Press.

Petrilli, S., \& Ponzio, A. (2006). La raffigurazione letteraria. Milan, Italy: Mimesis. 
Petrilli, S., \& Ponzio, A. (2014). Depicting the vision of the other in the novel and film. Bakhtin, Pasolini, Deleuze. In M. Cavagna \& C. Maeder (Eds.), Philology and Performing Arts: A Challenge (pp. 289-307). Louvain-la-Neuve, Belgium: UCL Presses Universitaires De Louvain.

Petrilli, S., \& Ponzio, A. (2016). Lineamenti di semiotica e di filosofia del linguaggio. Un contributo all'interpretazione del segno e all'ascolto della parola. Perugia, Italy: Guerra Edizioni.

Ponzio, A. (2002). La differenza non indifferente. Comunicazione, migrazione, guerra. Milan, Italy: Mimesis. (Original work published 1994)

Ponzio, A. (2012). La rivoluzione bachtiniana. Bari, Italy: Levante; La revolución bajtiniana. El pensamiento de Bajtin y la ideologia contemporanea. Madrid, Spain: Catedra.

Ponzio, A. (2015). Tra semiotica e letteratura. Introduzione a Michail Bachtin. Milan, Italy: Bompiani. (Original work published 1992).

Ponzio, A. (2016). La coda dell'occhio. Letture del linguaggio letterario senza confini nazionali. Rome, Italy: Aracne.

Ponzio, A. (2018). Linguistica generale, scrittura letteraria e traduzione. Perugia, Italy: Guerra Edizioni.

Ponzio, A., Petrilli, S., \& Ponzio, L. (2012). Interferenze, Carmelo Bene, Pasolini e dintorni. Milan, Italy: Mimesis. Schechner, R., \& Wolford, L. (Eds.). (1997). A Grotowski Sourcebook. London, UK: Routledge.

Slowiak, J., \& Cuesta, J. (2007). Jerzy Grotowski. London, UK: Routledge.

Stanislavsky, K. (1967). My Life in Art (Vol. 1). (J. Robbins, Trans.). London, UK: Menthuen.

Stanislavsky, K. (2008a). My Life in Art (Vol. 2). (J. Benedetti, Trans.). Abingdon, UK: Routledge.

Stanislavsky, K. (2008b). An Actor's Work (J. Benedetti, Trans.). Abingdon, UK: Routledge. doi: $10.4324 / 9780203936153$

Stanislavsky, K. (2010). An Actor's Work on a Role (J. Benedetti, Trans. \& Ed.). Abingdon, UK: Routledge. Vološinov, V. N. (1927). Frejdizm. Moscow, Leningrad, Russia. 
Susan Petrilli (Bari, Italy) is Professor of Philosophy and Theory of Languages at the University of Bari "Aldo Moro", Bari, Italy and Visiting Research Fellow at The University of Adelaide, South Australia. She is Vice-President of the International Association for Semiotic Studies, 7th Sebeok Fellow of the Semiotic Society of America and Fellow of the International Communicology Institute. She directs a number of book series and sits on the editorial board of several international journals. Her principal research areas include Philosophy of Language, Semiotics, Translation Theory. She has lectured as International Visiting Professor at universities in Australia, China, Brazil, Mexico, Canada, USA, South Africa, and across Europe. As translator and editor, she has promoted the works of Victoria Welby, Charles S. Peirce, Charles Morris, Mikhail Bakhtin, Thomas Szasz, Thomas A. Sebeok and Ferruccio Rossi-Landi. With co-author Augusto Ponzio she has introduced the seminal concept of "semioethics". Among her recent publications: with Mouton De Gruyter, Signifying and Understanding. Reading the Works of Victoria Welby and the Signific Movement (2009), Sign Studies and Semioethics. Communication, Translation and Values (2014); with Transaction, Sign Crossroads in Global Perspective. Semioethics and Responsibility (2010), Expression and Interpretation in Language (2012), The Self as a Sign, the World, and the Other. Living Semiotics (2013), Victoria Welby and the Science of Signs. Significs, Semiotics, Philosophy of Language (2015); with Mimesis Altrove e altrimenti. Filosofia del linguaggio, critica letteraria e teoria della traduzione con Bachtin (2012), Digressioni nella storia. Dal tempo del sogno al tempo della globalizzazione (2017); with Mimesis International, Challenges to Living Together. Transculturalism, Migration, Exploitation (2017); with Peter Lang, The Global World and Its Manifold Faces. Otherness as the Basis of Communication (2016); with Legas, Signs, Language and Listening. Semioethic Perspectives (2019). Her writings have been translated into French, Serbian, Spanish, Portuguese, German, and Chinese. 